\title{
Ulusal Kültür, Örgüt Kültürü ve İş Güvenliği Kültürüi İlişkisi: Hofstede'nin Güç Mesafesi ve Belirsizlikten Kaçınma Boyutları Açısından Türkiye Özelinde Bir Değerlendirme
}

\author{
Ümit Deniz İLHAN* ～Derya ALIMANOĞLU YEMIŞÇİ**
}

\begin{abstract}
$\ddot{O} Z$
Toplumu oluşturan bireylerin davranışlarının ardında yatan baskın ve belirleyici bir unsur olan ulusal kültür, bir arada yaşamaya yardımcı olan bütünleştirici bir yapıdır. Ulusal kültür, sadece sosyal yaşamda kendisini göstermekle kalmamakta, aynı zamanda çalışma hayatında önemli bir rol oynayarak örgüt kültürüne de etki etmektedir. Örgüt kültürünün bir alt sistemi olan iş güvenliği kültürü de benzer şekilde bu etkiler ışı̆̆ında şekillenmektedir. Böylece hem örgüt kültürünün hem de iş güvenliği kültürünün ulusal kültürün bir yansıması olduğu düşüncesiyle bu çalışmada Hofstede'nin Kültürel Boyutlar Teorisi'nde yer alan ve Türkiye'de yüksek olarak belirlenmiş olan güç mesafesi ve belirsizlikten kaçınma boyutları açısından ulusal kültürün iş güvenliği kültürü üzerindeki etkileri değerlendirilmiştir. Bu çerçevede benimsenmiş olan literatür taramast yöntemi ile ulusal kültür, örgüt kültürü ve iş güvenliği kültürü literatürü gözden geçirilerek birbirleri ile olan ilişkisi ortaya konmuş ve bu ilişsi, Türkiye özelinde güç mesafesi ve belirsizlikten kaçınma boyutları açısından yorumlanmıştır. Çalışmanın vardiğı sonuç, Türkiye'de yüksek olan güç mesafesi ve belirsizlikten kaçınmanın, iş güvenliği kültürü üzerinde olumsuz etkileri olduğu yönündedir.
\end{abstract}

Anahtar Kelimeler: Ulusal Kültür, Örgüt Kültürü, İş Güvenliği Kültürü, Güç Mesafesi, Belirsizlikten Kaçınma

JEL Sinıflandirması: M00, M14, M19

\section{The Relationship between National Culture, Organizational Culture, and Occupational Safety Culture: A Review of Turkey from the Perspective of Hofstede's Power Distance and Uncertainty Avoidance Dimensions}

\begin{abstract}
National culture, which is the dominant and decisive factor behind the behavior of individuals who make up the society, is an integrative structure that helps to live together. National culture not only manifests itself in social life but also plays an important role in working life and affects organizational culture. Occupational safety culture, which is a sub-system of organizational culture, is similarly shaped in the light of these effects. Thus, with the idea that both organizational culture and occupational safety culture reflect national culture, in this study, the effects of national culture on occupational safety culture were examined in terms of power distance and uncertainty avoidance dimensions, which are high in Turkey according to Hofstede's Theory of Cultural Dimensions. In this context, by adopting literature review method, studies in national culture, organizational culture, and occupational safety culture were set forth and Turkey was examined in
\end{abstract}

\footnotetext{
* Dr. Pınar Süt, İnsan Kaynakları Departmanı, umit_ilhan@ @otmail.com, ORCID Bilgisi: 0000-0003-3565-0938

*** Dr. Öğr. Üyesi. Manisa Celal Bayar Üniversitesi, İktisadi ve İdari Bilimler Fakültesi, derya.yemisci@cbu.edu.tr, ORCID Bilgisi: 0000-0003-3340-6763
} 
Ümit Deniz Illhan \& Derya Alimanoğlu Yemiş̧̧i / Ulusal Kültür, Örgüt Kültürü ve İş Güvenliği Kültürü Ilişskisi: Hofstede'nin Güç Mesafesi ve Belirsizlikten Kaçınma Boyutları Açısından Türkiye Özelinde Bir Değerlendirme terms of power distance and uncertainty avoidance. The study concludes that high power distance and high uncertainty avoidance in Turkey have negative effects on occupational safety culture.

Key Words: National Culture, Organizational Culture, Occupational Safety Culture, Power Distance, Uncertainty Avoidance

JEL Classification: M00, M14, M19

\section{GİRIŞ}

Her toplumun kendi karakteristiğiyle şekillenmiş olan bir kültürel yapısı vardır. Tarihsel süreç içinde sonraki kuşaklara aktarılarak gelişen ve canlı kalmaya devam eden bu yapı -ulusal kültür-, toplumu oluşturan bireylerin davranışları üzerinde belirleyici ve bütünleştirici bir unsurdur (Guiso vd., 2006). Öte yandan ulusal kültür, çalışma hayatında önemli bir rol oynayarak küçük topluluklar olarak düşünülebilen örgütlerin kültürüne de etki etmektedir. Bu noktada örgüt kültürünün ulusal kültürden bağımsız olduğunu söylemek mümkün olmamaktadır (Hartnel vd., 2011). Öyle ki örgüt üyeleri, içinde bulundukları toplum kültürünü örgüt bünyesinde yeniden harmanlamakta ve kendi kültürel yapılarını oluşturmaktadırlar. $\mathrm{Bu}$ doğrultuda örgüt üyelerinin de örgüt kültüründen etkilenmemeleri kaçınılmazdır (Wasti, 1995). Dahası, örgüt kültürünün bir alt sistemi olan iş güvenliği kültürü de benzer şekilde bu etkiler 1şığında şekillenmektedir (Irani ve Oswald, 2009). Bu bağlamda iş güvenliği kültürünün de temelde ulusal kültür doğrultusunda oluştuğunu ifade etmek mümkündür. Nitekim ulusal kültür, çok sayıda örgütsel davranışla ilişkilendirilmiş olup, iş güvenliği kültürü de bunlardan biridir (Keiser, 2017).

Diğer yandan gerek sanayi öncesi, gerekse sanayi sonrası toplum yapılarında sürekli bir güvenlik arayışı içinde olunduğuna dikkat çekmekte fayda vardır. Ancak özellikle Sanayi Devrimi ile birlikte gelişen teknolojilerin, birçok sağlık ve güvenlik tehdidini de beraberinde getirmesiyle, çalışma hayatında güvenlik ihtiyacı düzeyinin arttığı bir gerçektir (Kılkış, 2011). Bu bağlamda günümüze değin iş güvenliğini tehdit eden faktörlerden korunma yöntemleri araştırılarak çalışma düzenini ve çalışma şartlarını da içeren çeşitli yasa, yönetmelik ve standartlar geliştirilmiştir. Buna rağmen, süreç içinde mevcut yasaların, yönetmeliklerin ve standartların çalışanların sağlık ve güvenliğini sağlamak için yeterli olmadığı gözlenmiştir (Tharaldsen vd., 2010). Nitekim Türkiye'de 6331 Sayılı İş Sağlığı ve Güvenliği Kanunu (T.C. Resmi Gazete, 30.06.2012. Say1: 28339) da sadece tazmin değil, önlemler açısından getirmiş olduğu yükümlülükler açısından ümit verici olmakla birlikte kanun çerçevesindeki yasal düzenlemelerin, iş güvenliğini sağlamak açısından tek başına yeterli olmadığ1 düşünülmektedir (Çiftçi, 2016). Bu durumda çalışanların iş sağlığ 1 ve güvenliği ile ilgili tutum ve davranışları üzerinde etkili olan iş güvenliği kültürü, insan faktörünün güvenliği sağlamadaki rolünü açıklayan anahtar bir kavram olarak dikkatleri çekmektedir (Arezes ve Miguel, 2003). Öyle ki iş kazalarının önlenmesi ve oranının azaltılmasında yasal ve teknik düzenlemelerin yeterli olmadığ görüldüğünden, çalışma hayatında insan faktörünün de en az diğer faktörler kadar önemli olduğu anlaşılmaktadır (Keser ve Kümbül-Güler, 2016). Bu doğrultuda düşünüldüğünde, ulusal kültürün, çalışanların davranışı üzerinde önemli bir etkiye 
sahip olduğu gerçeği dikkat çekmektedir (Demirbilek, 2005; Nazariana vd., 2017). $\mathrm{Bu}$ nedenle kültürel farklılıkların çalışmayla ilgili tutum ve davranışlarla ilişkisi odağında ulusal kültürün iş güvenliği kültürü araştırmalarına dâhil edilmesi ve anlaşılması ihtiyacı açıktır (Mearns ve Yule, 2009).

Tüm bu açıklamalar göz önünde bulundurularak bu çalışma, ulusal kültürün örgüt kültürüne ve dolayısıyla iş güvenliği kültürüne olan etkisinin kültürel farkl1lıklar üzerine öncül araştırmacılardan Hofstede'nin (1980) Kültürel Boyutlar Teorisi'nde ortaya koyduğu üzere Türkiye'de ulusal kültürün belirgin özelliklerinden olan yüksek güç mesafesi ve yüksek belirsizlikten kaçınma boyutları bağlamında literatür taraması yöntemi benimsenerek ele alınması açısından özgün bir değer taşımaktadır. Özellikle güç mesafesi boyutu ve belirsizlikten kaçınma boyutunun ele alınmasının nedeni, ulusal kültür ve iş güvenliği kültürü arasındaki ilişkiyi ele alan çalışmaların çoğunda bu iki boyutun birlikte açıklayıcılığ1 yönündeki yaygın görüştür (Antonsen, 2009; Mearns ve Yule, 2009; Schubert ve Dijkstra, 2009; Starren vd., 2013; Terzi, 2004). Böylece çalışma, bir yandan ulusal kültür, örgüt kültürü ve iş güvenliği kültürü literatürüne katk1 sağlarken, bir yandan da ulusal kültürün iş güvenliği kültürüne etkisi göz önünde bulundurularak Türkiye'de iş güvenliği kültürünün geliştirilmesi için sunduğu önerilerle uygulayıcılara rehberlik etmeye katkı sağlayacaktır.

Bu çerçevede çalışmanın ilk bölümünde öncelikle ulusal kültür kavramı ele alınarak benzer kavramlarla olan ilişkisi açıklanmış ve insan davranışları üzerindeki rolü aktarılmıştır. Sonrasında literatürdeki tanımlar 1şığında örgüt kültürüne değinilmiş, örgüt kültürünün, bir örgütün diğerinden farklılaşmasında oynadığı role odaklanılmıştır. Daha sonra güvenlik ihtiyacının toplumsal değişim sürecine bağlı olarak geçirdiği aşamalar açıklanarak iş güvenliği kültürü ile ilgili temel bilgiler ortaya konmuştur. Çalışmanın ikinci bölümünde ilk olarak ulusal kültür, örgüt kültürü ve iş güvenliği kültürü ilişkisi hakkında genel bir değerlendirme yapılmıştır. Nihayetinde Türkiye özelinde iş güvenliği kültürü, Hofstede (1980)'nin Kültürel Boyutlar Teorisi'nde yer alan güç mesafesi ve belirsizlikten kaçınma boyutları açısından yorumlanmıştır. Bu çerçevede sonuç bölümünde yapılan bu değerlendirmeler tartışılmış ve sonraki araştırmalara öneriler sunulmuştur.

\section{LITERATÜR TARAMASI}

\section{A. Ulusal Külttür}

Kültür, karmaşık ve çok boyutlu yapısıyla, geçmişten günümüze birçok bilim dalının ilgilendiği bir konu olmuştur. Bu nedenle her bilim dalının bakış açısı çerçevesinde farklı unsurlarına dikkat çekilerek anlam kazanmıştır. Psikoloji, sosyoloji, edebiyat, yönetim, iletişim bunlardan sadece bir kaçıdır (Bram, 1953). Tek bir tanımını yapmanın mümkün olmadığı kültür, antropologlar Kroeber ve Kluckhohn (1952) tarafindan bu gibi farklı bilim dallarının ilgilendiği unsurlara odaklanılarak, 164 tanım çerçevesinde değerlendirilmiştir. Bununla birlikte benzer disiplin çatısı altında olan araştırmacılar dahi ortak bir tanım üzerinde hemfikir olamamış ve kavrama farklı açılardan yaklaşmışlardır (Haviland, 2002). 
Ümit Deniz İlhan \& Derya Alimanoğlu Yemişçi / Ulusal Kültür, Örgüt Kültürü ve İs Güvenliği Kültürü Illişkisi: Hofstede'nin Güç Mesafesi ve Belirsizlikten Kaçınma Boyutları Açısından Türkiye Özelinde Bir Değerlendirme

Kültürün tanımı ile ilgili bir fikir birliği bulunmamakla birlikte bu çalışmanın da ilgi odağını oluşturmuş olan Tylor'un (1871) "Primitive Culture" orijinal adlı kitabında yapmış olduğu tanım, kapsayıcılı̆̆ 1 nedeniyle literatürde sıklıkla başvurulan tanımlardan olmuştur. Tylor, ilgili eserde "kültür, toplumun bir üyesi olarak insanın edindiği bilgi, inanç, sanat, ahlak, hukuk, gelenek ve diğer yetenek ve alışkanlıkları içeren karmaşık bir bütündür" ifadesini kullanmıştır. Yapılan tanımdan, kültürün belirli bir toplum içindeki insanların algılama, düşünme, akıl yürütme, harekete geçme ve etkileşimde bulunmaları için bilişsel yönergeler sağlayan ortak inanç, değer ve tutum gibi süreçleri kapsadığ 1 anlaşılmaktadır (İlhan, 2019).

Kuşaktan kuşağa aktarılan kültür, durağan olmayıp, zaman içinde değişerek gelişmektedir. Bu anlamda kültürel değişim, hem bireysel hem de toplumsal düzeydeki değerlerin önceliklerinin değişmesini kapsayan ve süreklilik arz eden dinamik bir evrimsel süreçtir (Guiso vd., 2006). Bu noktada kültürün değer ile olan ilişkisi dikkat çekmekte ve birlikte açıklanması, kavramın anlaşılmasına 1şık tutmaktadır. Nitekim değerlerin kültürel bilgi olduğu ve kültürel birikimler üzerine kurulduğu literatürde çokça tartışılan konulardan olmuştur (Allport, 1961; Kluckhohn, 1951; Rokeach, 1973). Toplumdaki bireylerin değerleri kabul edip içselleştirmesine paralel olarak değerler ya sonraki kuşaklara aktarılmakta ya da zamanla kaybolmaktadır. Morey ve Luthans (1985) da kültürün uzun bir süreç sonucu oluştuğunu, köklerinin geçmişe dayandığını ve geleceğe uzandığını belirtmekte, ayrıca kültürel öğrenmenin değerlerin bir kuşaktan diğerine aktarılmasıyla meydana geldiğini, zaman içinde geliştiğini ifade etmektedir. Böylece, kültürün bir toplumsal bütünleşmeye sebep olduğu ve bu toplumsal bütünleşmenin sürekliliğini de değerlerin belirlediği yorumu yapılabilmektedir (Illhan, 2019).

Diğer yandan insan davranışlarında etkin bir şekilde belirleyici unsur olan kültür, aynı zamanda ancak insanın etkin rolü ile sonraki kuşaklara aktarılarak gelişmektedir. Çünkü kültür, bir toplumun üyesi olarak insanın, yaşayarak, yaparak öğrendiği ve diğerlerine aktararak öğrettiği karmaşık bir etkileşim bütündür (Güvenç, 2002). Sosyal bir varlık olan insan, tüm yaşamı boyunca aile, okul, sosyal çevre ve iş çevresi gibi içinde bulunduğu her türlü ortamda bilinçli ya da bilinçsiz bir öğrenme etkileşiminde bulunmaktadır (Kağıtçıbaşı, 2013). Bu süreçte içinde bulunulan kültür, gelenek, görenek, inanç, coğrafya gibi birçok faktörün etkisiyle şekillenmekte ve bu şekillenme, bütün bir yaşam boyunca devam etmektedir. Gerçekten doğduğu andan yaşamının sonuna kadar insan, içinde bulunduğu toplumun her türlü kültürel etkisi altında kalmaktadır. Bu etkileşim yoluyla edinilmiş kültür ise içselleştirilerek zaman içinde toplumun ve dolayısıyla toplumun parçası olan bireyin bir karakteristiği haline gelmektedir (Kottak, 2012).

Kuşaklar arası aktarım yoluyla gelişen kültür, bireylerin ve toplumların doğal olarak içinde bulundukları andaki tercihlerini belirlemektedir (Guiso vd., 2006). Bu bakımdan kültür aynı zamanda gelecekteki tercihlerin de önceden kestirilebilmesine olanak tanımaktadır. Bu konuda Hofstede (1980), kültürün beklenen davranışlar toplamı olduğuna dikkat çekmiştir. Hofstede vd. (2010) de 
ayrıca içinde bulundukları kültürün etkisi ile bireylerin zaman içinde çok fazla değişmeyerek özü itibariyle korunan bir zihinsel program taşıdığı ve bu zihinsel programın o bireyin benzer durumlarda benzer davranışlar göstermesine neden olduğunu ileri sürmüşlerdir.

\section{B. Örgüt Kültürü}

1970'lerde Batılı toplumların yaşadığı ekonomik durgunluk karşısında bir Doğu ülkesi olan Japonya'nın uluslararası pazarlara olan hâkimiyeti, o döneme kadar tartışmasız üstünlüğe sahip olan Batılı ülkelerin yönetim anlayışlarının sorgulanmasına neden olmuştur (Cavaleri ve Obloj, 1993). Bu dönemde araştırmacılar, örgütlere toplumun küçük birer parçası olarak yaklaşmış ve örgütlerin ulusal kültürü yansıttı̆̆ına dikkat çekerek, insan faktörü odağında örgüt kültürünün önemini tartışmaya başlamıştır (Smircich, 1983). Bu anlayış, aynı ulusal kültürü paylaşan örgütlerin farklı düzeylerde verimliliğe sahip olmalarını da göz önünde bulundurarak, araştırmacıların bakış açılarını daha mikro düzeye yöneltmiş ve her örgütün kendisine has kültürel yapısının varlığına dikkat çekmiştir (Schein, 1988). Böylece bireylerin örgüt içindeki davranışlarını anlamlandırabilmek için kültürel kavramlar incelenmeye başlanmıştır. Dönemin egemen anlayışı ise örgütsel verimliliğin, örgüt kültüründen etkilendiği yönünde olmuştur (Deal ve Kennedy, 1982; Peters ve Waterman, 1982). Bu anlamda örgüt kültürünün, özellikle 1980 'li yıllardan itibaren yönetim disiplininin en önemli çalışma alanlarından birisi olduğunu söylemek doğru olacaktır (Smircich, 1983).

Literatürde örgüt kültürü tanımlanırken daha ziyade örgütte genel kabul görmüş ve çalışanların davranışlarına rehberlik eden değer, inanç, varsayım, kural, gelenek ve norm gibi unsurlara dikkat çekilmektedir (Deal ve Kennedy, 1982). Bu tanımlardan bazıları şöyle sıralanabilmektedir: "Örgütü bir arada tutan sosyal veya normatif bir birleştirici" (Kast ve Rosenzweig, 1985); "örgüt üyelerinin bir amacl gerçekleştirmeye devam etmesine yardımcı olan değerler bütünü" (Nahavandi ve Malekzadeh, 1999); "kişilerin belirli bir hedefe ulaşma yolunda grup halinde çalışmasını sağlayan kural ve gelenekler" (Peters ve Waterman, 1982). Bunlarla birlikte, bu konu hakkında öncül araştırmacılardan Schein (1983) ise örgüt kültürünü "bir grubun geliştirdiği ve çeşitli durumlar karşısında algısını, düşüncesini ve tepkisini belirleyen kabul edilmiş varsayımlar dizisi" olarak ifade etmiştir. Benzer şekilde Cameron (2013) da "örgüt kültürü, örgüt üyeleri tarafindan oluşturulmakta ve üyelerin duygularını, düşüncelerini ve davranış kalıplarını etkilemektedir" şeklinde görüş bildirmiştir.

$\mathrm{Bu}$ doğrultuda toplumsal yapı ile kıyaslandığında küçük topluluklar olarak düşünülebilen örgütlerin de kendilerine özgü kültürlerinden bahsetmek mümkündür (Vural ve Akıncı, 2003). Elbette örgüt kültürü, örgütün içinde yer aldığ 1 toplumun kültüründen bütünüyle ayrı bir kültüre sahip değildir, ancak bireylerin örgüte taşmış oldukları kültürün, örgüt üyelerince yeniden yorumlanmas ile oluşmaktadır. Bu bağlamda toplum kültüründen etkilenerek oluşan örgüt kültürü, farklı kültür mozaiğine sahip örgüt üyelerinin sosyalleşmeleri ile kendi içlerinde ortak bir kültürel sistem oluşturmalarıdır (Eren, 1998). 
Ümit Deniz İlhan \& Derya Alimanoğlu Yemişçi / Ulusal Kültür, Örgüt Kültürü ve İş Güvenliği Külttürü Illişkisi: Hofstede'nin Güç Mesafesi ve Belirsizlikten Kaçınma Boyutları Açısından Türkiye Özelinde Bir Değerlendirme

Tıpk1 toplum üyelerinin içinde bulundukları ulusal kültürden etkilenerek çoğunlukla o kültürel unsurlara göre yaşadıkları gibi, bir örgütte çalışanların da örgüt kültüründen etkilenmelerinin kaçınılmaz olduğu belirtilmektedir (Wasti, 1995). Nitekim yukarıda aktarılan tanımlardan da, örgüt kültürünün bilinçli veya bilinçsiz olarak, çalışanların duygu, düşünce ve davranış biçimlerini belirlediği anlaşılmaktadır (Hartnell vd., 2011). Tüm çalışanlar ile birlikte zaman içinde oluşturulan değerlere dayanan bu öğrenme neticesinde ortaya çıkan örgüt kültürü, çalışanlar için davranışsal kodların belirleyicisi olma niteliği taşıdığı gibi örgütlerin misyon, vizyon, hedef ve stratejiler oluşturmaları için de rehberlik etmektedir (Wiener, 1988). Bu bakımdan örgüt kültürünün, örgüt içindeki ve dışındaki olay ve olguların anlamlandırılması için ortak bir alg1 çerçevesi oluşturduğu ileri sürülmektedir (Kuh ve Whitt, 2000). Nitekim örgüt kültürü bir yandan çalışanlar için ortak davranış kalıpları geliştirmesi bakımından çalışanlara yapılması gerekenler konusunda yol göstererek örgütteki içsel birlik ve bütünlüğü sağlamakta, bir yandan da örgütlerin değişen çevre koşullarına bu birlik ve bütünlük içinde uyum göstererek varlıklarını sürdürmelerinde rol oynamaktadır (Erkmen ve Ordun, 2001).

\section{C. İş Güvenliği Külttürü}

Evrensel nitelikte bir temel insan ihtiyacı olan güvenlik, emniyet içinde olmayı ifade etmektedir. Bu bakımdan bir tehlike karşısında korunma, tehlike anında ise kaçınma ve kurtulma anlamına geldiğinden, tehlike düzeyi ile doğru orantılı bir şekilde ortaya çıkmaktadır (Yazgan, 1992). Çalışma hayatı açısından bakıldığında, her ne kadar sanayi öncesi dönemde bugünkü anlamıyla bir çalışma ilişkisinden bahsedilemeyecek olsa da çalışma ile ilişkilendirilebilecek süreçler mümkün olduğundan, güvenlik ihtiyacının ilkel toplumlara değin dayandığ söylenebilmektedir (Reese, 2008). Ancak tehlike düzeyi açısından yaklaşıldığında, Sanayi Devrimi ile birlikte gelişen teknolojilerin çalışma ilişkilerine yansımasıyla yaşanan endüstrileşme, seri üretim gibi dönüşümlerin birçok sağlık ve güvenlik tehdidini beraberinde getirmesiyle güvenlik ihtiyacının düzeyinin de arttığ bilinmektedir (Kılkış, 2011). Bu nedenle günümüze kadar gelen süreçte, işyerlerinde iş güvenliğini tehdit eden mekanik, kimyasal, fiziksel ve psiko-sosyal faktörlerden korunma yöntemleri araştırılarak çalışma düzenini ve çalışma şartlarını da içeren kurallar ve kanunlar geliştirilmiştir. Bu da gerek sanayi öncesi gerekse sanayi sonrası toplum yapılarında sürekli bir güvenlik arayışı içinde olunduğunu göstermektedir (Çiftçi, 2016).

Bu bağlamda iş güvenliği kültürünü kavramsallaştırma ihtiyac1, ilk olarak 1986 yılında yaşanan Çernobil Nükleer Santral Kazası sonrasında 1985 yılında Uluslararası Atom Enerjisi Kurumu (International Atomic Energy Agency-IAEA) (1986) tarafindan oluşturulmuş olan Uluslararası Nükleer Güvenlik Danışma Grubu (International Nuclear Safety Advisory Group-INSAG) ${ }^{1}$ tarafindan yayınlanan ve meydana gelen kazanın olası nedenlerinin sorgulandığı raporda yer almıştır. Raporda, iş güvenliği kültürünün zayıflığı, kazanın nedenlerinden biri

${ }^{1}$ Yeni adı, Uluslararası Nükleer Güvenlik Ajansı'dır. 
olarak gösterilse de ancak 1991 yılında yayınlanmış olan yeni düzenlemeleri içeren raporda (IAEE, 1991), güvenlik kültürü kapsamlı olarak tanımlanarak nasıl ölçülmesi gerektiği açılanmıştır. IAEE (1991)'nin tanımına göre güvenlik kültürü, örgütün sağlık ve güvenlik programlarının yeterliliğine, tarzına ve uygulamadaki sürekliliğine karar veren birey ve grupların değer ve tutum örüntülerinin bir ürünüdür. Literatürdeki çok sayıda iş güvenliği kültürü tanımı arasından öne çıkan Cooper (2000) tarafindan "örgüt kültürünün bir alt sistemi ve örgütün sağllk ve güvenlik performansinın sürdürülmesiyle ilgili davranışlara ve örgüt üyelerinin tutumlarına etki eden düşünceler" olarak ifade etmiştir. Kavram, Hale (2000) tarafindan "çalışanların, risk ve risk kontrol sistemleri ile ilgili hareket ve tepkilerinin nasl olmasl gerektiğini belirleyen norm ve değerleri tanımlayan tutumlar, inançlar ve algılar" olarak tanımlanmıştır. Fang vd. (2006) ise iş güvenliği kültürünü "örgütün güvenlik konusunda sahip olduğu bir dizi geçerli gösterge, inanç ve değer" olarak kavramsallaştırmıştır.

Zararla sonuçlanabilecek olası tehlikelerin önceden saptanması ve gerekli önlemlerin alınması hayli önem taşımaktadır. $\mathrm{Bu}$ nedenle modern anlamda güvenlik yönetimi, sistem hatalarından ziyade, risk değerlendirme ve iş güvenliği kültürüne odaklanmaktadır. Zira iş güvenliği kültürü, örgütün her kademesinde çalışanların maruz kalabileceği risklerin azaltılmasına yönelen, kaza ve meslek hastalıklarının önlenmesi ile ilgilenen uygulamalar ve prosedürler bütünüdür (Muniz vd., 2007). Bu bakımdan örgüt üyelerinin güvenlik tutumlarını geliştirdiği, sürdürülebilir kıldığ1 ve güvenli davranışı teşvik ettiği için önemli olduğu savunulmaktadır (Zohar, 1980). Böylece bir örgütte olumlu bir iş güvenliği kültürü, güvenlik yönetimi için de uygun bir alt yapı sağlamaktadır (Ek vd., 2014).

Araştırmalar, iyi gelişmiş bir iş güvenliği kültürüne sahip örgütlerde daha az kaza yaşanabileceğini ortaya koymaktadır (Lee ve Harrison, 2000). Bu anlamda iş güvenliği kültürünün ne ölçüde gelişmiş olduğu örgütlerin ekonomik başarısı açısından da önemli bir performans ölçütüdür. Nitekim kazaları önlemek, tedavi etmekten daha etkili, kolay ve az maliyetlidir. Daha açık bir ifadeyle güvenlik kültürünün oluşturulması neticesinde çalışanların risk ve tehlikelerin farkında olmaları ile güvensiz davranışlardan sakınmalarını sağlamak mümkün olabilmektedir. Böylece sağlik ve güvenlik konusunda benzer inanç, fikir ve algıların geliştirilmesi ile kaza, yaralanma ve hastalıkları azaltmak olanaklı olabilmektedir. Bu nedenle, örgütlerde sağllğ̣ ve güvenliği korumak için etkin bir güvenlik kültürü oluşturulması hayli önem arz etmektedir (Reiman ve Oedewald, 2007).

\section{ULUSAL KÜLTÜR, ÖRGÜT KÜLTÜRÜ VE İŞ GÜVENLİĞi KÜLTÜRÜ İLIŞKISIS}

\section{A. Genel Değerlendirme}

Ulusal kültür, örgüt kültürü ve iş güvenliği kültürü literatürü dikkate alındığında, iş güvenliği kültürü, örgüt kültürünün bir alt sistemi olduğundan, ulusal kültürün alt sistemi olan örgüt kültüründen ve doğal olarak ulusal kültürden bağımsız olarak ele alınması bütüncül bir yaklaşım olmayacaktır (Taras vd., 2010). Dahası, kültürel farklılıkların çok sayıda örgütsel tutum ve davranışla ilişkili 
Ümit Deniz İlhan \& Derya Alimanoğlu Yemişçi / Ulusal Kültür, Örgüt Kültürü ve İş Güvenliği Külttürü Illişkisi: Hofstede'nin Güç Mesafesi ve Belirsizlikten Kaçınma Boyutları Açısından Türkiye Özelinde Bir Değerlendirme

olduğu düşünüldügünde, ulusal kültürün anlaşılması ve iş güvenliği araştırmalarına entegre edilmesi ihtiyacı açıktır (Oyserman vd., 2002a; Taras vd., 2010). Hofstede ve Peterson (2000) da bireylerin sosyalleşmesinin çalıştıkları örgütün kültüründen ziyade, en temelde ve derinde ulusal kültür tarafindan şekillendiğini belirtmektedirler. $\mathrm{Bu}$ çerçevede yapılan birçok çalışma da ulusal kültürün görece baskın etkisi konusunda hemfikirdir. Örneğin Jung vd. (2008), çok uluslu bir şirket çalışanları üzerinde yürüttükleri araştırmalarında, çalışanların içinde bulundukları örgüt kültürüne kıyasla büyük ölçüde kendi ulusal kültürlerini oluşturan unsurların etkisinde olduklarını ortaya koymuşlardır. Mearns ve Yule (2009) tarafından gerçekleştirilmiş olan bir diğer araştırma da farklı ulusal kültürlerden bireylerin iş güvenliği yönetimi uygulamaları ile ilgili beklentilerinde farklılık olduğunu göstermektedir. Benzer şekilde birçok çalışma, ülkeler arasında bölgesel farklı1ıklar olmasına rağmen, ulusal kültürün, örgütler üzerinde birleştirici bir etkisi olduğunu ortaya koymuştur (Huang ve van de Vliert, 2004; Ryan vd., 1999). O halde ulusal kültürden etkilenerek çalışanların davranışlarında bir kaldıraç görevi yerine getiren örgüt kültürü ile ilişkisi bağlamında iş güvenliği kültürünün, ulusal kültürün bir yansıması olduğu sonucuna varılmaktadır (Demirbilek, 2005; Noort vd., 2015).

Esasen değerlerden beslenen ulusal kültürün (Allport, 1961; Kluckhohn, 1951; Rokeach, 1973) ve etki ettiği örgütsel kültürün, iş güvenliği algılarının temeli olarak hizmet eden örgütsel politikaları, uygulamaları ve prosedürleri doğrudan şekillendirerek iş güvenliği kültürünü etkilediği iddia edilmektedir (Aumann ve Ostroff, 2006; Kopelman vd., 1990). Yukarıdan aşağıya doğru olan bu süreç, ulusal kültürle başlamakta, bu da örgütsel kültürün ve iş güvenliği kültürünün üzerine kurulduğu değerleri etkilemektedir (Erez ve Gati, 2004; Schneider vd., 2013). Bu yaklaşım, kültürün değerle olan ilişkisi odağında iş güvenliği kültürü üzerindeki etkisine ilişkin teorik açılamalara dayanmaktadır (Erez ve Gati, 2004; Locke, 1991; Oyserman vd., 2002b; Schneider, 1987). Nitekim bu teoriler, litertaürde sıkça değerlerin kültürel birikimler üzerine kurulduğunu ve ulusal kültürün sırasıyla örgütsel kültürü ve iş günvenliği kültürünü doğrudan şekillendirdiğini iddia etmek için başvurulmuştur (Keiser, 2017). Bu durumda bir toplum içinde gelişen ve çalışma davranışlarını da şekillendiren ulusal kültürün iş güvenliği ile ilgili politikaları, uygulamaları ve prosedürleri etkilememesi kaçınılmazdır (Noort vd., 2015).

\section{B. Hofstede'nin Güç Mesafesi ve Belirsizlikten Kaçınma Boyutları Açısından Türkiye Değerlendirmesi}

Farklı kültürlerin toplumlar üzerindeki etkilerini belirlemeye yönelik yapılan araştırmalar (Inkeles ve Levinson, 1969; Schwartz, 2007; Kluckhohn ve Strodtbeck, 1961; Taras vd., 2010), literatürde önemli bir yer tutmakta ve kültürel farklar konusunda birçok kültür boyutuna işaret etmektedir. Bu sayede toplumlar için genellenebilecek ortak kültürel unsurlara ulaşmanın mümkün olacağ 1 düşünülmektedir (Bhagat ve McQuaid, 1982). Kültürler arasında gözlemlenen farklı1ıkları açıklamak için yapılan bu araştırmalardan, Hofstede'nin (1980) ortaya koyduğu kültürel boyutlara dair teori, ulusal kültür ve örgüt kültürü alanında en çok 
kabul gören ve araştırmalarda tercih edilen olmuştur (Lim, 2001; Schimmack vd., 2005; Taras vd., 2010).

1970'lerde Hofstede, çok uluslu bir şirket olan IBM'in dünya çapındaki şirketlerinde bir çalışma yürütmüş ve Türkiye'nin de aralarında bulunduğu farklı ülkelerden 100.000 'den fazla çalışandan elde ettiği veriler ile toplumların kültürel değerlerine dair teorisini geliştirmiştir (Hofstede, 1980). Böylece ilk analiz çerçevesinde "güç mesafesi (power distance)", "bireycilik-toplulukçuluk (individualism-collectivism)", "erillik-dişilik (masculinity-femininity)" ve "belirsizlikten kaçınma (uncertainty avoidance)" olmak üzere dört boyut önermiştir. 2000-2010 arasında yürütmüş olduğu sonraki çalışmalarda ise kuramına "uzun vadeli-kısa vadeli oryantasyon (long-short term orientation" ve "hoşgörükısitlama (indulgence-restraint)" olmak üzere iki boyut daha ekleyerek boyut sayısını altı olarak belirlemiştir. Buna göre i) güç mesafesi, gücün kullanımı ve dağılımının kabulü ile ii) belirsizlikten kaçınma, bilinmeyen bir gelecek karşısında ortaya konan tavır ile iii) bireycilik-kolektivizm, bireysel ve grup çıarlarının göreli önemi ile iv) erillik-dişilik, toplumsal cinsiyet rollerinin tüm kültüre sirayet etmesi ile v) uzun vadeli-kısa vadeli oryantasyon, insanların çabalarına odaklanma seçimi ile vi) hoşgörü-kısıtlama, yaşamdan zevk almayla ilgili temel insan arzularının kontrolüne karş1 tatmin ile ilgilidir (Hofstede, 1980; Hofstede, 2011; Hofstede vd., 2010). Hofstede'nin bu sinıflandırma altında ortaya koyduğu kültür boyutlarını bütünüyle incelemek bu çalışmanın kapsamı dışında olmakla birlikte, çalışmada bunlardan güç mesafesi ve belirsizlikten kaçınma boyutları ele alınmıştır. Bunun nedeni, ulusal kültür ve iş güvenliği kültürü arasındaki ilişkiyi ele alan birçok çalışmada özellikle güç mesafesi boyutu ve belirsizlikten kaçınma boyutunun birlikte açıklayıcı olduğu yönündeki yaygın görüştür (Antonsen, 2009; Mearns ve Yule, 2009; Schubert ve Dijkstra, 2009; Starren vd., 2013; Terzi, 2004).

Düşük ve yüksek düzeyde olmak üzere iki açıdan değerlendirilen güç mesafesi, toplumlardaki tüm bireylerin eşit güce sahip olmadığg gerçeğiyle ilgilidir ve yukarıda da ifade edildiği üzere bu eşitsizliklere karşı kültürel duruşu ifade etmektedir. Bu bakımdan güç mesafesi, örgütlerin daha az güçlü üyelerinin gücün eşit olmayan bir şekilde dağılmasını ne ölçüde kabul ettiğini görmek açısından bir çerçeve çizmektedir (Hofstede, 1980). Buna göre güç mesafesinin düşük olduğu toplumların en belirgin özelliği, ast-üst ilişkisinde belirgin bir hiyerarşik yapının söz konusu olmamasıdır. Böylece düşük güç mesafesi algısına sahip çalışanlar, yöneticilerle nispeten eşit seviyede olduklarını düşünebilmektedirler (Botero ve van Dyne, 2009). Bu nedenle bu tip toplumlarda firsat eşitliğine daha çok önem verildiği söylenebilmektedir. $\mathrm{Bu}$ durum, çalışanların karar alma sürecine katılımının yüksek seviyede olması ile sonuçlanmaktadır (Brockner vd., 2001). Böylesi bir katılım, çalışanların her konuda görüşlerini rahatlıkla dile getirebilmelerine de olanak sağlamaktadır. Böylece çalışanların yöneticileri ile bilgi ve görüşlerini paylaşabilmeleri kolay olabilmekte, yöneticilerin de bu paylaşımları dikkate aldığı bir çalışma ortamından bahsetmek mümkün olabilmektedir (Huang vd., 2005). Buna karşın güç mesafesinin yüksek olduğu toplumlarda, güç merkezileşmiştir ve ast-üst ilişkisinde katı bir hiyerarşik yapı söz 
Ümit Deniz İlhan \& Derya Alimanoğlu Yemişçi / Ulusal Kültür, Örgüt Kültürü ve İş Güvenliği Külttürü Illişkisi: Hofstede'nin Güç Mesafesi ve Belirsizlikten Kaçınma Boyutları Açısından Türkiye Özelinde Bir Değerlendirme

konusudur. Hiyerarşik yap1, yöneticilerin gücünün sorgulanmasını da caydırmaktadır. Bu nedenle yüksek güç mesafesi algısına sahip çalışanlar, yöneticilerinin kendileri üzerinde kontrol etme gücü olduğunu düşünerek görüşlerini de rahatlıkla dile getirememektedirler (Botero ve van Dyne, 2009). Bu gibi toplumlarda çalışanlar karar verme süreçlerine de daha az katılım gösterebilmektedirler (Brockner vd., 2001). Hatta yüksek güç mesafesi, çalışanların yöneticilerinden rehberlik alma konusundaki beklenti düzeylerinin de yüksek olduğu anlamına geldiğinden, gücü elinde tutanların ayrıcalıklara sahip olmasını ve eşitsizliği de beraberinde getirmektedir (Hofstede, 2001).

Güç mesafesi boyutu gibi, düşük ve yüksek düzeyde olmak üzere iki açıdan değerlendirilen belirsizlikten kaçınma ise bilinmeyen bir gelecek karşısında ortaya konan tavır ile ilgilidir ve toplumun, geleceğin asla bilinememesi durumunda geleceği kontrol etmeye mi çalıştığını yoksa geleceği akışına bırakmayı mı tercih ettiğini ifade etmektedir (Hofstede 1984). Geleceğe dair bu belirsizlik, kaygıyı da beraberinde getirmekte ve farklı toplumlar bu kaygı ile farklı yöntemlerle başa çıkmaktadır (Hofstede vd., 2010). Belirsizlikten kaçınma düzeyinin düşük olduğu toplumlarda (örneğin İngiltere, Danimarka, İsveç, İrlanda), bireyler belirsizlik durumunu daha kolay tolere edebilmektedirler (Hofstede, 2001). Bu yapıdaki toplumlarda belirsizlik, normal yaşamın bir parçası olarak görüldüğünden risk almak, yaratıcılık ve yenilik önemli değerler olarak öne çıkmaktadır. Ayrıca kuralların sınırlandırıcı olduğu düşünülmekte ve uzman görüşünden ziyade ortak sağduyuya önem verilmektedir (Hofstede, 1984). Belirsizlikten kaçınma düzeyinin yüksek olduğu toplumlarda (örneğin Japonya, Portekiz, Yunanistan, İspanya, Türkiye) ise bireyler riskli ve sonucu belirli olmayan durumlardan sakınma eğiliminde olup tercihleri daha ziyade tahmin ya da kontrol edilebilir durumlardan yanadır. $\mathrm{Bu}$ yapıdaki toplumlarda kurallar ve uzman görüşleri her zaman çok önemlidir (Hofstede vd., 2002). Ayrıca belirsizlik durumlarının yalnızca resmi, açık kurallar ve yasalarla değil, aynı zamanda resmi olmayan, örtük kurallarla da yönetilmeye çalıştığını belirtmek gerekmektedir (Hofstede, 1984).

Hofstede (1980)'nin Kültürel Boyutlara Teorisi'ne göre Türkiye, 53 ülke arasında 66 puanla güç mesafesinin yüksek olduğu, 85 puanla belirsizlikten kaçınmanın çok yüksek olduğu ülkeler grubunda yer almaktadır. İlk olarak güç mesafesi boyutu açısından ele alındığında, bu durum, Türkiye'de gücün kullanımı ve dağılımı ile ilgili eşitsizliği kabul etme düzeyinin yüksek olduğu anlamına gelmektedir (Demirhan, 2017). Bu da Türkiye'de hiyerarşik, bağımlı, yöneticilerin genellikle ulaşılmaz görüldüğü bir yapının hâkim olduğunun göstergesidir (Wasti ve Erdil, 2007). Gücün merkezde toplandığı bu yapıda, çalışanlar işin yürütülüşü ile ilgili konularda ideal olarak "baba" figüründeki yöneticilerin kontrolü altında olup, belirlenen kurallara güvenmekte ve bel bağlamaktadırlar. $\mathrm{Bu}$ yapının, babanın, ailenin diğer fertleri tarafından yaşça büyük ve saygıya değer bir kişi olarak yer aldığı Türk aile yapısında da açıkça görüldüğü ifade edilmektedir. Toplumsal hayattaki bu anlayışın çalışma hayatına yansıması ise sosyal statü göstergelerine fazlaca değer verilip sayg1 gösterildiğinden, yöneticilerin daha güçlü olduğunun kabul edilmesi, direktiflerinin sorgulanmadan yerine getirilmesidir 
(Öğüt ve Kocabacak, 2008). Dahası çalışanlar ne yapılması gerektiğinin kendilerine söylenmesini ve hatta denetlenmesini beklemektedirler. Dolayısıyla örgüt üyelerinde sürekli bir kontrol edilme beklentisi söz konusudur (Wasti, 1995). $\mathrm{Bu}$ anlayışın bir diğer tezahürü, güçsüz olanların, güçlü ve nüfuslu olanlardan çekinen ve kendilerine ne yapmaları gerektiğinin söylenmesinden rahatsız olmayan bir anlayışta olmalarıdır (Demirhan, 2017). Ayrıca iletişim de bu bağlamda dolaylı olduğundan, kararlara katılım da herkes için aynı düzeyde olmamaktadır (Wasti, 2000). Belirsizlikten kaçınma boyutu açısından ele alındığında ise Türkiye'nin sahip olduğu yüksek puan, belirsizlikten kaçınma düzeyi yüksek bir yapıya işaret ettiğinden kanunlara ve kurallara büyük bir ihtiyaç olduğu anlamına gelmektedir. Nitekim Türkiye'de kurallar çerçevesinde hareket etmek ve üstlerinin kendileri için yol göstericiliğinin kabulü çerçevesinde bir anlayış hâkimdir (Barutçugil, 2011). Bu durum, Türkiye'de belirsizliği azaltmak için liderlere sığınma eğilimi içinde olunduğunu göstermektedir (Sargut, 1994). Bu nedenle Türk kültüründe faaliyetlerde katı bir yapılaşma ön plana çıkmakta ve tüm süreçlerin yasa, yönetmelik, yönerge gibi yazılı kurallara dönüştürülmesine neden olmaktadır. Örneğin, Türkiye'de trafikte hız sınırına uyma konusunda bir yandan radara yakalanma bir yandan da yüksek miktarda ceza ödeme söz konusu olduğunda, kural ihlalinden kaçınılması bu durum ile ilişkilendirilebilmektedir (Çiftçi, 2016).

Yüksek güç mesafesinin iş güvenliği kültürünü olumsuz etkilediği yönündeki bir çok araştırma sonucu (Hetherington, 2007; Lu vd., 2016; Reader vd., 2015; Tharaldsen vd., 2010) dikkate alındığında, Türkiye açısından da bu durumun olumlu bir iş güvenliği kültürü oluşturulmasında önleyici bir rol oynayabileceği düşünülmektedir (Akyürek vd., 2015). Her şeyden önce üstten asta doğru akan iletişim, bir komuta zinciri üzerinden ve çoğunlukla tek yönlü olarak yapıldığ1 muhtemel olduğundan, Türk kültüründeki yüksek güç mesafesinin doğurduğu hiyerarşik ilişsi ve iletişim bağlamında yöneticilerin karar alma sürecinde çalışanların görüşlerini almaya ve geri bildirimde bulunmaya çok az dikkat ettiği düşülmektedir. $\mathrm{Bu}$ durum, gözlemlenen güvenlik sorunlarının ve endişelerinin iletilmesi de dâhil olmak üzere iletişim ve kararlara katılımın önüne engel olmaktadır. Herhangi bir tehlike veya risk karşısında çalışanlar yöneticileri ile aralarında olan hiyerarşi gereği durumu bildirmek yerine kendilerine söylenene itaat etmekle yetinmektedirler (Koydemir vd., 2014). Bu eğilim, iş güvenliğinin önceliklendirildiği kültürlerel bir yapıyı değil, aksine iş güvenliğinin gözardı edildiği ilişki odaklı yapıları ve davranışları doğurmaktadır (Akyürek vd., 2015). Literatürde de yüksek güç mesafesinin kararlara katılımın önünde engel olduğu sıklıkla vurgulanmaktadır (Huang vd., 2005; Reader vd., 2015; Seymen ve Korkmaz, 2017). Bu kapsamdaki hiyerarşik yapı, nispeten daha az güce sahip olanların otoriteyi sorgulamalarını da engellemektedir. Öyle ki güç mesafesinin yüksek olduğu kültürlerde çalışanlardan yalnız yöneticilerin direktifleri doğrultusunda davranmaları beklendiğinden bir iş güvenliği kültürü oluşturmak istendiğinde, üst yönetim tarafından güvenlikle ilgili kararların alındığı ve çalışanların buna uymasının beklendiği bir anlayış hâkimdir (Gyekye ve Salminen, 2005). Böylece yöneticilerinin kararlarını eleştirmek gibi algılanabileceğinden, 
Ümit Deniz İlhan \& Derya Alimanoğlu Yemişçi / Ulusal Kültür, Örgüt Kültürü ve İş Güvenliği Külttürü Illişkisi: Hofstede'nin Güç Mesafesi ve Belirsizlikten Kaçınma Boyutları Açısından Türkiye Özelinde Bir Değerlendirme

çalışanların etraflarında olan olumsuzlukları görmezden veya duymazdan gelmeleri ve bu gibi durumları yöneticilerine bildirmek konusunda geri durmaları söz konusu olabilmektedir (Şekerli ve Gerede, 2011) Bu bağlamda çalışanlar, yöneticilerinin kararlarını sorgulayamadıkları durumlarda ve herhangi bir konu için önerilerini yönetime sunamadıklarında iş güvenliği faaliyetlerinde katılımcı olamamakta ve yalnız yöneticilerinin iş güvenliği açısından doğru ve yanlış olarak belirlediklerini kabul etmektedirler. Bu durumda olumlu bir iş güvenliği kültürünün sağlanması bakımından en önemli girdilerden olan çalışan görüşlerinin alınması sınırlanmış hatta engellenmiş olmaktadır (Lu vd., 2016; Mearns ve Yule 2009; Reader vd., 2015). Keser vd. (2015)'nin ulusal kültür boyutlarının ülke düzeyinde ölümcül iş kazaları üzerindeki etkisini araştırdığı çalışmanın sonuçları, bu açıdan önemli bulgular taşımaktadır. Araştırmacılar, bu çalışmada, güç aralığ 1 boyutu ile ülke düzeyindeki ölümcül iş kazaları sayısında pozitif yönlü bir ilişki olduğu bulgusunu ortaya koymuşlardır. Buna göre güç aralığının yüksek olduğu toplumlarda iş güvenliğinin olumsuz etkilendiği anlaşılmaktadır.

Öte yandan belirsizlikten kaçınma düzeyinin yüksek olması da literatürde daha ziyade iş güvenliği kültürü ile olumsuz ilişkilendirilmektedir (Burke vd., 2008; Noort vd., 2015; Reader vd., 2015). Öncelikli olarak belirsizlikten kaçınma düzeyinin yüksekliği, iş güvenliğinin sağlanmasında yazılı ve yaptırımı olan kuralların varlığını zorunlu kılmaktadır. Bu durum, bireylerin yasal kurallardan ziyade, üstlerinin kendilerine yazılı ve hatta çoğunlukla sözlü olarak yöneltmiş olduğu kurallara daha fazla uyum göstermeyi tercih etmeleri nedeniyle çoğu kez iş güvenliğini sağlamaya yönelik yasal kuralları ötelemelerine neden olmaktadır (Fruhen vd., 2013). Böylesi bir durum, örgütlerde iş güvenliği ile ilgili yeterli düzeyde güvenlik kültürü oluşturulmaması halinde çalışanların iş güvenliğini tehlikeye sokmaktadır. Öyle ki bireyler yasal düzenlemeler neticesinde uyulmas zorunlu kurallar ve örgütleri tarafından uymaları beklenen kurallar arasında seçim yapmak durumunda kaldıklarında, yaptırımın daha ziyade işini kaybetmek olduğu örgüt tarafindan belirlenen kuralları önceliklendireceğinden, iş güvenliğ kültürünün olumsuz etkilenmesi de kaçınılmaz görünmektedir (Çiftçi, 2016). Böylesi bir durumda iş güvenliğinin olumsuz etkilenmesi, temelde örgüt tarafından belirlenen kurallar ile bireylerin yapılandırılmış senaryolara odaklanmasını arttırması ve alternatif senaryolara daha az odaklanmalarına neden olması ile ilişkilidir (Noort vd., 2015). Bununla birlikte belirsizlikten kaçınma düzeyinin yüksek olmasının doğurduğu yazılı ve yaptırımı olan kuralların varlığı, i) daha az yeniliğe ve belirsiz ve dinamik iş güvenliği senaryolarını yönetmek için statik prosedürlere ve protokollere daha fazla güvenmeye (Helmreich ve Merritt, 1998); ii) belirsiz ve muhtemelen sosyal olarak tehdit edici sonuçları olan eylemlerde (örneğin hatayı kabul etme, açıkça konuşma) bulunma istekliliğinin azalmasına (Soeters ve Boer, 2000); iii) yeni ortaya çıkan risklere karşı mevcut stratejileri değiştirme ve kaynakları yeniden tahsis etme gibi durumlarda harekete geçme konusunda daha az esneklik göstermeye (Waarts ve van Everdingen, 2005); iv) güvenliğin nasıl yönetileceğine dair farklı görüşlere karşı toleransın azalmasına (Hofstede, 1983) yol açabilmektedir. 
Türkiye açısından yukarıda açıklanan görece yüksek güç mesafesi ve belirsizlikten kaçınma düzeyi gösteren kültürel değerler bir arada yorumlandığında, iş güvenliği bakımından risk teşkil eden durumlarda i) güç mesafesi kapsamında, çalışanların, şüphe de etse yöneticilerinin sözlerini doğru olarak kabul ettiği hatta bir anlamda itaat ettiği ve ii) belirsizlikten kaçınma kapsamında, çalışanların, yöneticilerinin daha önce ortaya koyduğu kuralları uygulamayı tercih ettikleri çıkarımı yapılmaktadır (Özutku, 2019). Yani Türk toplumunda belirsizliği azaltmak için güç mesafesi aralığı yüksek tutulmaktadır (Demirhan, 2017). Hatta belirsizliğin üstesinden gelinemediğinde bireyler yaratıcıya, sığınarak belirsizliği azaltma yoluna gitmektedirler (Sargut, 1994). Diğer yandan, Hofstede'in Kültürel Boyutlar Teorisi'ne göre Türkiye'de yüksek olan belirsizlikten kaçınma düzeyi neticesinde bireylerin kural arayışı içinde olmaları, iş güvenliği ile ilgili kurallara daha çok uyum göstereceklerini düşündürttüğünden iş kazalarının yüksekliğiyle ilgili çelişkili bir durum oluşturuyor gibi bir algıya neden olabilmektedir. $\mathrm{Bu}$ noktada Türkiye'de iş güvenliği ile ilgili kuralların yeterince önemsenmemesi, aksine iş güvenliği açısından risk oluşturan bazı kuralların ise hiç sorgulanmadan kabul edilmesi, yüksek olan güç mesafesi aralığı ile açıklanabilmektedir (Çiftçi, 2016). Öyle ki bir üretim hattında iş güvenliğine yönelik tehdit olabilecek sorunları algılayan çalışanların, bu riskleri bizzat gözlemlemelerine rağmen, riskin olmadığını söyleyen yöneticilerine inanmaları, belirsizlikten kaçınma ile birlikte güç aralığı çerçevesinde otoriteye itaat etmeleri ile açılanabilmektedir (Özutku, 2019).

Tersi durum üzerinden değerlendirildiğinde ise düşük güç mesafesinin iş güvenliği kültürü açısından daha olumlu olduğu fikrini destekleyen birçok çalışma vardır (Lu vd., 2016; Mearns ve Yule 2009; Reason, 1997). Nitekim tüm çalışanların yöneticileri ile işbirliği yaptı̆̆ ve karar alma sürecinin kolektif olduğu bu yap1, iş güvenliğin ilişkin çalışanların kendi görüşlerini sunmalarına izin vermektedir. Bu da gerek yasalar gerekse örgüt tarafından oluşturulan iş güvenliği kurallarına karşı gözlemlenen herhangi bir aksaklığın rapor edilme düzeyini arttırarak ileride gerçekleşme olasılığı olan iş kazalarını engelleme gücünü açığa çıarmaktadır (Çiftçi, 2016). Ayrıca bu vesileyle yönetim becerileri de gelişmiş olan çalışanlar, örgüt içinde önemli bir rol oynadıklarını ve güçlü bir beraberlik duygusu yaşadıklarını hissettikleri için iş güvenliği konusunda inisiyatif alma konusunda motivasyonları da artmaktadır (Dartey-Baah, 2015). Cronje (2011)'nin çalışmasında da yüksek güç mesafesi, çalışanların kendilerine güvenmemelerinin ve inisiyatif alamamalarının nedeni olarak açıklanmakta, düşük güç mesafesi ise inisiyatif alma konusunda motive edici olarak ileri sürülmektedir. Benzer şekilde düşük belirsizlikten kaçınma da literatürde sıklıkla iş güvenliği kültürü açısından olumlu görülmektedir (Burke vd., 2008; Noort vd., 2015; Sığr1 ve Tığl1, 2006; Şerifoğlu ve Sungur, 2007). Bu bağlamda belirsizlikten kaçınma düzeyinin iş güvenliği kültürü açısından olumlu sonuçlara yol açmasının gerekçelerini Noort vd., (2015), böylesi bir durumda yöneticiler ve çalışanların i) güvenlik sorunları hakkındaki iletişim içinde olduklarına, ii) iş güvenliğini iyileştirme konusunda farklı ve yeni fikirlere açık olduklarına, iii) mevcut iş güvenliği politikaları 
Ümit Deniz İlhan \& Derya Alimanoğlu Yemişçi / Ulusal Kültür, Örgüt Kültürü ve İş Güvenliği Külttürü Illişkisi: Hofstede'nin Güç Mesafesi ve Belirsizlikten Kaçınma Boyutları Açısından Türkiye Özelinde Bir Değerlendirme

tarafindan daha az kısitlandıklarına ve iv) hataları bildirme konusunda daha cesur olduklarına vurgu yaparak sıralamışlardır. Burke vd. (2008) de belirsizlikten kaçınmanın yüksek olması durumu üzerinden açılama yaparak, böylesi bir yapının kapsamlı bir iş güvenliği kültürünü sınırlayan yapılandırılmış yaklaşımlarla sonuçlanmasının muhtemel olduğunu ileri sürerek belirsizlikten kaçınma düzeyinin düşük olduğu durumlara özgü yapılandırılmamış bir yaklaşımın ise kapsamlı bir iş güvenliği kültürünün yayılımını sağlayacağına işaret etmişlerdir.

\section{SONUÇ}

Ulusal kültür, toplumu oluşturan bireylerin davranışlarının önemli bir yordayıcısıdır (Guiso vd., 2006; Jones ve Alony, 2007). Bu bakımdan ulusal kültürde güvenlik ile ilgili benimsenen değerler, örgütlerde iş güvenliği kültürünün oluşmasında son derece etkilidir. Çünkü iş güvenliği kültürü, örgüt kültürünün ve dolayısıyla örgüt kültürünün de etkisi altında olduğu ulusal kültürün bir yansımasıdır (Demirbilek, 2005). Bu nedenle, iş güvenliği kültürüne yönelik yapılan çalışmalarda ulusal kültürün göz ardı edilmesi mümkün olmayacağı gibi özellikle güvenlik ile ilgili değerler açısından ulusal kültürün daha detaylı olarak irdelenmesi önem arz etmektedir (Koydemir vd., 2014). Bu bakımdan iş güvenliğinin sağlanmasında yasal düzenlemeler son derece gerekli ve önemli olsa da bu düzenlemeler yanında insan faktörüne etki eden ulusal kültür de hayli belirleyicidir (Çiftçi, 2016). İş güvenliği kültürünün kavramsallaştırma ihtiyacını doğuran Çernobil Nükleer Santral Kazası'nda da, insan faktörünün güvenliği sağlamadaki rolü açıkça görülmüştür (Dursun, 2012). Benzer şekilde Türkiye'deki iş kazaları incelendiğinde, iyi organize edilmiş bir yönetim yapısı, iyi eğitilmiş çalışanlar, iyi yönetilmiş bir kontrol mekanizması ve kültür odaklı bir sistem olmadan sadece yasalar çerçevesinde kanun ve kurallar, iş güvenliği uygulamalarının başarılı bir şekilde gerçekleştirileceği anlamına gelmemektedir (Keser vd., 2015). Ancak daha ziyade iş güvenliğinin yasal boyutu ele alınarak kültürel boyutu nispeten ikinci planda tutulmaktadır (Tharaldsen vd., 2010). Oysa yasal düzenlemeler birçok açıdan tek başına yeterli olmayıp ancak kültürel bağlam içinde anlam kazanmaktadır. Nitekim ulusal kültür çerçevesinde bireylerin güvenlik algısı, örgütlerin güvenlik algısına etki ederek iş güvenliği kültürünün temel belirleyicilerinden olmaktadır. Ayrıca yasal düzenlemelerin uygulanma düzeyi de kültüre dayalı algılar doğrultusunda şekillenmektedir (Koydemir vd., 2014). Bu nedenle mücadelede daha iyi sonuçlara ulaşmak için kültürün ulusal boyutlarının olası etkilerinin iş güvenliği ile ilgili sürece entegrasyonu önem arz etmektedir (Keser vd., 2015).

Bu çalışma, ulusal kültürün örgüt kültürü ve iş güvenliği kültürü üzerindeki etkisini ortaya koymak için çeşitli teorik ve ampirik açıklamalara dayanmaktadır. $\mathrm{Bu}$ açıklamalar, ulusal kültürün iş güvenliği kültürü için temel teşkil eden örgüt politikalarını, uygulamalarını ve prosedürlerini doğrudan şekillendirdiğini desteklemektedir. Bununla birlikte ulusal kültürün iş güvenliği kültürüne etkisinin değerlendirilmesinde Hofstede'nin Kültürel Boyutlar Teorisi'nde yer alan güç mesafesi ve belirsizlikten kaçınma boyutlarından yararlanılmıştır. Düşük ve yüksek güç mesafesi ve düşük ve yüksek belirsizlikten kaçınma olarak değerlendirilen bu 
boyutlara göre Türkiye için yüksek olarak belirlenmiş olan her iki boyut çerçevesinde ulusal kültürün iş güvenliği kültürünü genellikle olumsuz etkilediği çıkarımını yapmak mümkün olmaktadır.

Çalışma genelindeki açıklamalardan hareketle, olumlu bir iş güvenliği kültürü oluşturmak ve sürdürmek için ulusal kültürün dikkate alınması gerektiği söylenebilmektedir. $\mathrm{Bu}$ bakımdan örgütlerin yapması gereken, temelde ulusal kültür ve örgüt kültürü arasındaki etkileşimi verimli bir şekilde yöneterek iş güvenliği kültürü oluşturmak için izlenen tüm süreci, ilgili ulusal kültürü göz önünde bulundurarak yapılandırmaktır (Mearns ve Yule, 2009). Türkiye için ortaya konmuş olan yüksek güç mesafesi ve yüksek belirsizlikten kaçınma boyutları odağında değerlendirildiğinde, çalı̧̧anlar, yöneticilerin iş güvenliği ile ilgili kural ve düzenlemeleri önceden oluşturmasını, standartlaştırmasını ve hiyerarşik yapıya uygun komuta zinciri dâhilinde kendilerine iletmesini beklemektedirler. Bu tür bir çalışan yapısıyla karşılaşan yöneticiler, merkezi yap1, katı kurallar ve prosedürler, tek yönlü yukarıdan aşağıya iletişim ve sıkı denetim gibi mekanizmalarla daha verimli bir iş güvenliği kültürü belirleyebileceklerdir (Koydemir vd., 2014). Öyle ki çalışanlar iş güvenliği ile ilgili tüm sorumlulukların yönetime ait olduğunu ve kurallara uymaktan başka sorumlulukları olmadığını düşünmektedir. Bu nedenle kuralların çerçevesinin çok iyi yapılandırılmış olması ve denetlenmesi büyük önem taşımaktadır. Özellikle belirsizlikten kaçınmanın yüksek olması göz önünde bulundurulduğunda, örgütlerde iş güvenliği kurallarının gerek yazılı gerekse sözlü olarak açıkça ortaya konması ve üst yönetimin, iş güvenliği konusunda taviz vermeyeceğine yönelik tüm çalışanlara örnek olması gerekmektedir (Çiftçi, 2016). Ancak yüksek güç mesafesi ve belirsizlikten kaçınmanın iş güvenliği kültürü oluşturmadaki olumsuz etkileri dikkate alındığında, bu yapıyı besler nitelikte tutum ve davranışları devam ettirmektense bu etkileri olumluya çevirecek nitelikte tutum ve davranışlara yönelerek iş güvenliği kültürünü geliştirmenin daha doğru olacağ 1 düşünülmektedir. Nitekim katılıma ve açık bir iletişime olanak veren örgütlerin sorun çözme ve görüş birliği sağlama konusunda tarafların becerilerini geliştireceği bilinmektedir (Kılkış, 2011) Böylece olası tehlikelerin raporlanmasını cesaretlendiren türde özellikleri içinde barındıran bir yapının da desteklenmesiyle olumlu bir iş güvenliği kültürüne sahip olunacağı düşünülmektedir.

$\mathrm{Bu}$ durumda ulusal kültür ve iş güvenliği kültürü ilişkisi noktasından hareketle iş güvenliği kültürüne dönük uygulamaların sadece çalışma hayatında değil, toplumun her alanında ve tüm bireylerde geliştirilmesinin önemini vurgulamakta fayda vardır. Buradan hareketle, olumlu bir iş güvenliği kültürüne sahip olabilmek için, yasal düzenlemelerin yanı sıra, toplumsal kültüre yerleşecek ve tutumlara yansıyacak bir iş güvenliği kültürünün oluşturulması da gerekmektedir (Özutku, 2019). Bu nedenle, iş güvenliği kültürüne yönelik çalışmalar aile ortamından başlayarak eğitim sürecinde pekiştirilmeli ve tüm yaşam boyunca devam etmelidir. Bu sayede ulusal kültüre entegre olmuş bir iş güvenliği kültürü yaratılabilecektir (Çelik, 2008). Tozkoporan ve Taşoğlu (2011) tarafindan mavi yakalı çalışanlara yönelik yapılan araştırmada benzer bir tespit yapılmıştır. Buna göre iş kazalarında çalışanların güvensiz davranışları ile baş edebilmek için 
Ümit Deniz İlhan \& Derya Alimanoğlu Yemişçi / Ulusal Kültür, Örgüt Kültürü ve İş Güvenliği Kültürü Ilişsisi: Hofstede'nin Güç Mesafesi ve Belirsizlikten Kaçınma Boyutları Açısından Türkiye Özelinde Bir Değerlendirme

çalışanlarda iş güvenliği bilincinin oluşturulması ve güvenli davranış kalıplarının yerleştirilmesinde iş güvenliği kültürü anlayışının sadece çalışanlara değil topluma yerleştirilmesi gerekliliği vurgulamıştır. $O$ halde olumlu bir iş güvenliği kültürü ancak toplumsal düzeyde farkındalık ile bütüncül bir şekilde sağlanabilmektedir. $\mathrm{Bu}$ çerçevede i) bir yandan ulusal kültür dikkate alınarak iş güvenliği kültürü oluşturulurken, karşıllıklı etkileşim içinde olacakları göz önünde bulundurularak ulusal kültürde düşük güç mesafesi ve düşük belirsizlikten kaçınmayı besleyecek nitelikte politikalara önem verilmelidir; ii) bu süreçte tüm tarafların görüşleri alınarak sürecin her aşamasında tarafların katılımı sağlanmalıdır; iii) oluşturulan politikalar hem toplumsal hem de örgütsel düzeyde ilgili tarafların bilinçlendirilmesi ve katılımı dâhilinde uygulanmalıdır; iv) politikaların uygulanması, izlenmesi, değerlendirilmesi süreci bu katılımcı anlayış dâhilinde yürütülerek sürekli iyileşmesi sağlanmalıdır.

Çalışmanın birkaç kısıtı çerçevesinde sonraki çalışmalar için önerilerden söz etmek mümkündür. Buna göre Hofstede'nin Kültürel Boyutlar Teorisi'nin yalnız güç mesafesi ve belirsizlikten kaçınma boyutlarının ele alınması, ilk kısıt olarak sunulabilir. Önemle belirtmekte fayda vardır ki, iş güvenliği kültürünün bu iki boyut açısından değerlendirilmesi, kavramın altında yatan teorik ve felsefi varsayımların eleştirel bir incelemesinin temelini atmada etkili olmaktadır. Ancak, tüm vurguyu bu iki perspektif üzerinden yapmak, diğer boyutların odaklarını gözden kaçırmaya neden olabilir. Bu nedenle sonraki çalışmalarda diğer boyutların da incelenmesi, konuya daha bütüncül bir bakış açısı ile katkı sağlayabilecektir. Ayrıca her ne kadar ilgili teori, literatürde hâla sıklıkla başvurulan önemli referanslardan olsa da bu alanda diğer güncel teoriler takip edilebilir. Böylece sonraki çalışmaların, güncel teorilere dayanarak yapılacak değerlendirmeler çerçevesinde geliştirilmesi literatürdeki açığı kapatmaya yardımcı olacaktır. Zira literatürde hâla özellikle, ulusal kültürün iş güvenliği kültürünü nasıl etkileyebileceğini dair teorileştirmeye ve iş güvenliği uygulamaları için bunların sonuçlarını dikkate almaya ihtiyaç vardır.

\section{KAYNAKÇA}

Akyürek, F., Koydemir, S., ve Topçuoğlu, E. M. (2015). Türkiye'de güvenlik kültürü düzeyi ve bunu etkileyen toplumsal kültür ögeleri. The Journal of Europe - Middle East Social Science Studies, 1(2), 163-189.

Allport, G. W. (1961). Pattern and growth in personality. New York: Holt, Rinehart \& Winston.

Antonsen, S. (2009). Safety culture and the issue of power. Safety Science, 47, 183-191.

Arezes P. M. ve Miguel, A. S. (2003). The role of safety culture in safety performance measurement. Measuring Business Excellence, 7(4), 20-28.

Aumann, K. A. ve Ostroff, C. (2006). Multi-level fit: An integrative framework for understanding HRM practices in cross-cultural contexts. Research in multilevel issues içinde (Ed. F. J. Yammarino ve F. Dansereau). ss. 13-79. Bingley: Emerald.

Barutçugil, İ. (2011). Kültürlerarası farklılıkların yönetimi. İstanbul: Kariyer Yayınları.

Bhagat, R. ve McQuaid, S. (1982). Role of subjective culture in organizations: A review and directions for future research. Journal of Applied Psychology, 67, 653-685.

Botero, I. C. ve van Dyne, L. (2009). Employee voice behavior interactive effects of LMX and power distance in the United States and Colombia. Management Communication Quarterly, 23(1), 84-104. 
Brockner, J., Ackerman, G., Greenberg, J...ve Shapiro, D. (2001). Culture and procedural justice: The influence of power distance on reactions to voice. Journal of Experimental Social Psychology, 37(4), 300-315.

Bram, J. (1953). Culture: A critical review of concepts and definitions. American Sociological Review, 4, 442-443.

Burke, M. J., Chan-Serafin, S., Salvador, R...ve Sarpy, S. A. (2008). The role of national culture and organizational climate in safety training effectiveness. European Journal of Work and Organizational Psychology, 17, 133-152.

Cameron, K. S. (2013). A process for changing organizational culture. Handbook of organizational development içinde (Ed. T. G. Cummings). ss. 429-445. Thousand Oaks: Sage.

Cavaleri, S. ve Oblaj, K. (1993). Management systems: A global perspective. California: Wadsworth Publishing.

Cooper, M. D. (2000). Towards a model of safety culture. Safety Science, 36, 111-136.

Cronje, J. C. (2011). Using Hofstede's cultural dimensions to interpret cross-cultural blended teaching and learning. Computers \& Education, 56(3), 596-603.

Çelik, İ. (2008). Güvenlik kültürünün getirdikleri. İş ve Sağllk Güvenliği Dergisi, 38(8), 18-28.

Çiftçi, B. (2016). Türkiye'de toplumsal kültürün iş güvenliği kültürüne etkisi. Sosyal Güvenlik Dergisi, 7(2), 13-40.

Dartey-Baah, K. (2015). The impact of national cultures on corporate cultures in organisations. Academic Leadership, 9(1), 1-12.

Deal, T. E. ve Kennedy, A. A. (1982). Corporate cultures: The rites and rituals of corporate life. MA: Addison-Wesley.

Demirbilek, T. (2005). İş güvenliği kültürü. İzmir: Legal Yayınevi.

Demirhan, H. (2017) Etkin bir mali yönetim aracı olarak kamuda hesap verme sorumluluğu ve kültür ilişkisi: Türkiye açısından bir analiz. (Basılmamış Doktora Tezi). İzmir: Dokuz Eylül Üniversitesi.

Dursun, S. (2012). İs güvenliği kültürü. İstanbul: Beta Yayınları.

Ek, A., Runefors, M. ve Borell, J. (2014). Relationships between safety culture aspects: A work process to enable interpretation. Marine Policy, 44, 179-186.

Eren, E. (1998). Örgütsel davranış ve yönetim psikolojisi. İstanbul: Beta Basım Yayım.

Erez, M. ve Gati, E. (2004). A dynamic, multi-level model of culture: From the micro level of the individual to the macro level of a global culture. Applied Psychology: An International Review, 53, 583-598.

Erkmen, T. ve Ordun, G. (2001). Örgüt kültürü tipleri ile yönetim biçimleri arasındaki ilişkinin incelenmesine yönelik bir araştırma. 9. Ulusal Yönetim ve Organizasyon Kongresi Bildiri Kitabl. ss. 67-87.

Fang, D. P., Chen, Y. ve Louisa, W. (2006). Safety climate in construction industry: A case study in Hong Kong. Journal of Construction Engineering and Management, 132(6), 573-584.

Fruhen, L., Flin, R. ve McLeod, R. (2013). Chronic unease for safety in managers: A conceptualisation. Journal of Risk Research, 17, 969-979.

Guiso, L., Sapienza, P. ve Zingales, L. (2006). Does culture affect economic outcomes? Journal of Economic Perspectives, 20(2), 23-48.

Güvenç, B. (2002). Kültürün $A B C$ 'si. İstanbul: Yap1 Kredi Yayınları.

Gyekye, S. A. ve Salminen, S. (2005). Responsibility assignment at the workplace: A Finnish and Ghanaian perspective. Scandinavian Journal of Psychology, 46, 43-48.

Hale, A. R. (2000). Editorial: Culture's confusions. Safety Science 34, 1-14.

Hartnell, C. A., Ou, A. Y. ve Kinicki, A. (2011). Organizational culture and organizational effectiveness: A meta-analytic investigation of the competing values. Journal of Applied Psychology, 96(4), 677-694.

Haviland, W. A. (2002). Cultural anthropology. Wadsworth: Thompson Learning.

Helmreich, R. ve Merritt, A. C. (1998). Culture at work in aviation and medicine: National, organizational, and professional influences. Aldershot, UK: Ashgate.

Hetherington, C. (2007). Evaluating the antecedents and consequences of safety climate. (Basılmamış Doktora Tezi). Aberdeen: Aberdeen Üniversitesi. 
Ümit Deniz İlhan \& Derya Alimanoğlu Yemişçi / Ulusal Kültür, Örgüt Kültürü ve İş Güvenliği Kültürü Ilişsisi:

Hofstede'nin Güç Mesafesi ve Belirsizlikten Kaçınma Boyutları Açısından Türkiye Özelinde Bir Değerlendirme

Hofstede, G. (1980). Culture's consequences: International differences in work-related values. London: Sage.

Hofstede, G. (1983). The cultural relativity of organizational practices and theories. Journal of International Business Studies, 14, 75-89.

Hofstede, G. (1984). The cultural relativity of the quality of life concept. The Academy of Management Review, 9(3): 389-398.

Hofstede, G. (2001). Culture's consequences: Comparing values, behaviors, institutions and organizations across nations. London: Sage.

Hofstede, G. (2011). Dimensionalizing cultures: The Hofstede model in context. Online Readings in Psychology and Culture, 2(1), 1-26.

Hofstede, G., Hofstede, G. J. ve Minkov, M. (2010). Cultures and organizations: Software of the mind. Maidenhead: McGraw-Hill.

Hofstede G. ve Peterson, M. F. (2000). Culture: National values and organizational practices. Handbook of organizational culture and climate içinde (Ed. N. N. Ashkanasy, C. Wilderom ve M. F. Peterson). ss. 401-416. USA: Sage.

Hofstede G. J., Pedersen, P. B. ve Hofstede, G. (2002). Exploring cultue: Exercises, stories and synthetic cultures. USA: Nicholas Brealey Publishing.

Huang, X., van de Vliert, E. ve van der Vegt, G. (2005). Breaking the silence culture: Stimulation of participation and employee opinion with holding cross-nationally. Management and Organization Review, 1(3), 459-482.

Inkeles, A. ve Levinson, D. J. (1969). National character: The study of modal personality and sociocultural systems. The Handbook of Social Psychology, 4, 418-506.

International Atomic Energy Agency (IAEA). (1986). Summary report on the post-accident review meeting on the Chernobyl accident. International Safety Advisory Group, Safety Series No. 75-INSAG-1. Vienna: International Atomic Energy Agency.

International Atomic Energy Agency (IAEA). (1991). Safety culture: A report by the International Nuclear Safety Advisory Group. Safety Series No. 75-INSAG-4. Vienna: International Atomic Energy Agency.

Irani, F. S. ve Oswald, S. L. (2009). Workplace aggression: Is national culture a factor? The Business Renaissance Quarterly, 4(1), 63-89.

İlhan, Ü. D. (2019). Kuşaklar açısındna çalışma değerleri ve örgütsel bağlllık. Ankara: Nobel Bilimsel Yayıncilik.

Jones, M. L. ve Alony, A. (2007). The cultural impact of information systems -through the eyes of Hofstede- A critical journey. Issues in Informing Science and Information Technology, 4, 407419.

Jung, J., Su, X., Baeza, M. ve Hong, S. (2008). The effect of organizational culture stemming from national culture towards quality management deployment. The TQM Magazine, 20(6), 622635.

Kağıtçıbaş1, Ç. (2013). Günümüzde insan ve insanlar: Sosyal psikolojiye giriş. İstanbul: Evrim Yayınevi.

Kast, F. ve Rosenzweig, J. E. (1985). Organization and management. London: Mc. Graw-Hill.

Keiser, N. L. (2017). National culture and safety: A meta-analysis of the relationships between Hofstede's cultural value dimensions and workplace safety constructs. (Basılmamış Doktora Tezi). Texas: Texas A\&M Üniversitesi.

Keser, A., Gökmen, Y. ve Türen, U. (2015). The impacts of national culture on fatal occupational injuries. International Periodical For The Languages, Literature, and History of Turkish or Turic, 10, 567-588.

Keser, A. ve Kümbül-Güler, B. (2016). Çalışma psikolojisi. Kocaeli: Umuttepe Yayınları.

K1lkış, İ. (2011). İs sağllğ ve iş güvenliği. Sosyal Politika (Ed. Aysel Tokol ve Yusuf Alper). Bursa: Dora Yayınları.

Kluckhohn, C. (1951). Values and value orientations in the theory of action: An exploration in definition and classification. Toward a general theory of action içinde (Ed. T. Parsons ve E. Shils). ss. 388-433. Cambridge: Harvard University Press. 
Kluckhohn, F. R. ve Strodtbeck, F. L. (1961). Variations in value orientations. New York: Harper Collins.

Kopelman, R. E., Brief, A. P. ve Guzzo, R. A. (1990). The role of climate and culture in productivity. Organizational climate and culture içinde (Ed. In B. Schneider). ss. 282-318. San Francisco, CA: Jossey-Bass.

Kottak, C. P. (2012). Mirror for humanity: An introduction to cultural anthropology. New York: McGraw Hill.

Koydemir, S., Akyürek, F. ve Topçuoğlu, E. M. (2014). Çalışma hayatında ve günlük yaşamda güvenlik kültürü. Bilge Adamlar Stratejik Araştırmalar Merkezi Rapor No: 64, Ankara: Bilgesam Yayınları.

Kroeber, A. L. ve Kluckhohn, C. (1952) Culture: A critical review of concepts and definitions. Cambridge: Massachusetts.

Kuh, G. D. ve Whitt, E. J. (2000). Culture in American colleges and universities, organization and governance in higher education. Boston: Pearson.

Lee, T. ve Harrison, K. (2000). Assessing safety culture in nuclear power stations. Safety Science, 34, 61-97.

Lim, L. (2001). Work-related values of Malaysians and Japanese: A re-examination of Hofstede's propositions. Journal of Transnational Management Development, 6, 39-56.

Locke, E. A. (1991). The motivation sequence, the motivation hub, and the motivation core. Organizational Behavior and Human Decision Processes, 50, 288-299.

Lu, C. S., Hsu, C. N. ve Lee, C. H. (2016). The impact of seafarers' perceptions of national culture and leadership on safety attitude and safety behavior in dry bulk shipping. International Journal of e-Navigation and Maritime Economy, 4, 75-87.

Mearns, K. ve S. Yule. (2009). The role of national culture in determining safety performance: Challanges for the global oil and gas industry. Safety Science, 47, 777-785.

Morey, N. ve Luthans, C. F. (1985). Refining the displacement of culture and the use of scenes and themes in organizational studies. Academy of Management Review, 10(2), 219-229.

Muniz, B. F., Peon, J. M. M. ve Ordas, C. J. V. (2007). Safety culture: Analysis of the causal relationships between its key dimensions. Journal of Safety Research, 38, 627-641.

Nahavandi, A. ve Malekzadeh, A. R. (1999). Organizational behavior. New Jersey: Prentice-Hall.

Nazariana, A., Atkinsonb, P. ve Foroudic, P. (2017). Influence of national culture and balanced organizational culture on the hotel industry's performance. International Journal of Hospitality Management, 63, 22-32.

Noort, M. C., Reader, T. W., Shorrock, S. ve Kirwan, B. (2015). The relationship between national culture and safety culture: Implications for international safety culture assessments. Journal of Occupational and Organizational Psychology, 89, 515-538.

Oyserman, D., Coon, H. M. ve Kemmelmeier, M. (2002a). Rethinking individualism and collectivism: Evaluation of theoretical assumptions and metaanalyses. Psychological Bulletin, $128,3-72$.

Oyserman, D., Kemmelmeier, M. ve Coon, H. M. (2002b). Cultural psychology, a new look: Reply to Bond (2002), Fiske (2002), Kitayama (2002), and Miller (2002). Psychological Bulletin, $128,110-117$.

Ögüut, A. ve Kocabacak, A. (2008) Küreselleşme sürecinde Türk iş kültüründe yaşanan dönüşümün boyutları. Selçuk Üniversitesi Türkiyat Araştırmaları Dergisi, 23, 145-170.

Özutku, H. (2019). Kültürel boyutlar bağlamında örgütsel değerlerde ayrışma ve benzeşme: Fortune 500 Global ve Fortune 500 Türkiye listesindeki en beğenilen firmalar üzerine bir araştırma. International Review of Economics and Management. 7(1), 1-27.

Peters, T. J. ve Waterman, R. (1982). In search of excellence. New York: Harper \& Row.

Reader, T. W., Noort, M. C., Shorrock, S. ve Kirwan, B. (2015). Safety sans frontières: An international safety culture model. Risk Analysis, 35, 770-789.

Reason, J. T. (1997). Managing the risks of organizational accidents. Aldershot: Ashgate.

Reese, C. D. (2008). Occupational health and safety management: A practical approach. Florida: CRC Press. 
Ümit Deniz İlhan \& Derya Alimanoğlu Yemişçi / Ulusal Kültür, Örgüt Kültürü ve İş Güvenliği Kültürü Ilişsisi:

Hofstede'nin Güç Mesafesi ve Belirsizlikten Kaçınma Boyutları Açısından Türkiye Özelinde Bir Değerlendirme

Reiman, T. ve P. Oedewald (2007). Assessment of complex socio-technical systems -theoretical 1ssues concerning the use of organizational culture and organizational core task concepts. Safety Science, 45, 745-768.

Rokeach, M. (1973). The nature of human values. New York: The Free Press.

Ryan, A. M., McFarland, L., Baron, H. ve Page, R. (1999). An international look at selection practices: Nation and culture as explanations for variability in practice. Personnel Psychology, 52(2), 359-391.

Sargut, S. (1994). Kültürlerarası farklılaşma ve yönetim. Ankara: Verso Yayınları.

Schein, E. H. (1988). Organizational culture. MIT Sloan School of Management. Working Paper, No. 2088-88.

Schein, E. H. (1983). Organizational culture: A dynamic model. MIT Sloan School of Management. Working Paper, No. 170-911.

Schimmack, U., Oishi, S. ve Diener, E. (2005). Individulism: A valid and important dimension of cultural differences between nations. Personality and Social Psycology Review, 9(1), 17-31.

Schneider, B. (1987). The people make the place. Personnel Psychology, 40, 437-453.

Schneider, B., Ehrhart, M. G. ve Macey, W. H. (2013). Organizational climate and culture. Annual Review of Psychology, 64, 361-388.

Schubert, U. ve Dijkstra, J. J. (2009). Working safely with foreign contractors and personnel. Safety Science 47, 786-793.

Schwartz, S. H. (2007). A theory of cultural values and some implications for work. Applied Psychology: An International Review, 48(1), 23-47.

Seymen, O. A. ve Korkmaz, E. (2017). Örgütsel bağlllık ve örgütsel sessizlik ilişkisinde güç mesafesinin düzenleyici etkisi. Social Sciences Studies Journal, 3(8), 509-529.

Sığrı, Ü. ve Tığlı, M. (2006). Hofstede'nin belirsizlikten kaçınma kültürel boyutunun yönetselörgütsel süreçlere ve pazarlama açısından tüketici davranışlarına etkisi. Marmara Üniversitesi Íktisadi ve İdari Bilimler Dergisi, 21(1), 327-342.

Smircich, L. (1983). Concepts of culture and organizational analysis. Administrative Science Quarterly, 28(3), 339-358.

Soeters, J. L. ve Boer, P. C. (2000). Culture and flight safety in military aviation. The International Journal of Aviation Psychology, 10, 111-133.

Starren, A., Hornixk, J. ve Luijters, K. (2013). Occupational safety in multicultural teams and organizations: A research agenda. Safety Science, 52, 43-49.

Şekerli, E. B. ve Gerede, E. (2011) Kültürün EKY'ye etkileri ve Türk pilotların hofstede kültür boyutları açısından durumları. İş, Gü̈ç Endüstri İlişkileri ve İnsan Kaynakları Dergisi, 13(1), 17-38.

Şerifoğlu, U. K. ve Sungur E. (2007). İşletmelerde sağlik ve güvenlik kültürünün oluşturulması: Tepe yönetiminin rolü ve kurum içi iletişim olanaklarının kullanımı. Yönetim Dergisi, 18(58), 4150 .

Taras, V., Kirkman, B. L. ve Steel, P. (2010). Examining the impact of culture's consequences: A three-decade, multilevel, meta-analytic review of Hofstede's cultural value dimensions. Journal of Applied Psychology, 95, 405-439.

T.C. Resmi Gazete. 6331 Sayılı İş Sağlığı ve Güvenliği Kanunu. 30.06.2012. Sayı: 28339, Ankara: Başbakanlık Basımevi.

Terzi, A. R. (2004). Üniversite öğrencilerinin güç mesafesi ve belirsizlikten kaçınma algıları üzerine araştırma. Afyon Kocatepe Üniversitesi Sosyal Bilimler Dergisi, 4(2), 65-76.

Tharaldsen, J. E., Mearns, K. J. ve Knudsen, K. (2010). Perspectives on safety: The impact of group membership, work factors and trust on safety performance in UK and Norwegian drilling company employees. Safety Science, 48, 1062-1072.

Tozkoparan, G. ve Taşoğlu, J. (2011). İş sağlığı ve güvenliği uygulamaları ile ilgili iş görenlerin tutumlarını belirlemeye yönelik bir araştırma. Uludağ Üniversitesi İktisadi ve İdari Bilimler Fakültesi Dergisi, 30(1), 181-209.

Tylor, E. P. (1871). Primitive culture: Researches into the development of mythology, philosophy, religion, language, art, and custom. London: Bradbury Evans \& Co.

Vural, Z. ve Akıncı, B. (2003). Kurum kültürü ve örgütsel iletişim. İstanbul: İletişim Yayınları. 
Waarts, E. ve Van Everdingen, Y. (2005). The influence of national culture on the adoption status of innovations: An empirical study of firms across Europe. European Management Journal, 23, 601-610.

Wasti, S. A. (1995). Kültürel farklılaşmanın örgütsel yapı ve davranışa etkileri: Karşılaştırmalı bir inceleme. Orta Doğu Teknik Üniversitesi Geliştirme Dergisi, 22, 503-529.

Wasti, S. A. ve Erdil, S. (2007). Bireycilik ve toplulukçuluk değerlerinin ölçülmesi: Benlik kurgusu ve INDCOL ölçeklerinin Türkçe geçerlemesi. Yönetim Araştırmaları Dergisi, 7(1), 39-66.

Weiner, Y. (1988). Forms of value systems: A focus on organizational effectiveness and cultural change and maintenance. Academic Management Review, 13(4), 534-535.

Yazgan, T. (1992). İktisatçılar için sosyal güvenlik ders notları. İstanbul: Türk Dünyası Araştırmaları Vakfi Yayını.

Zohar, D. (1980). Safety climate in industrial organisations: Theoretical and applied implications. Journal of Applied Psychology, 65, 96-102.

\section{SUMMARY}

Societies have their cultural structures. This structure, which is responded to as national culture, is the dominant and determining factor behind the behavior of the individuals who make up the society (Guiso et al., 2006). National culture also keeps societies together and in this respect, it acts as an integrative tool. The culture acquired in the socialization process of individuals and developing through intergenerational transfers gives hints about the future preferences of individuals and societies while determining their current preferences Hofstede (1980). National culture not only manifests itself in social life but also plays an important role in working life and affects organizational culture (Hartnel et al., 2011). So, members of the organization re-blend the national culture they are in within the organization and create their cultural structures. In this respect, organizational culture is formed only by reinterpreting the culture that individuals overflow to the organization by the members of the organization. It is inevitable that those working in an organization are affected by the culture of the organization, just as the members of the society live by being influenced by the national culture they are in (Wasti, 1995). Indeed, it is not possible to think that organizational culture has a culture completely separate from the culture of the society in which the organization takes place. Therefore, organizational culture plays an important role in differentiating one organization from another. Moreover, occupational safety culture, which is a sub-system of organizational culture, is similarly shaped in the light of these effects. In this context, it would be correct to say that occupational safety culture is formed in line with national culture (Keiser, 2017).

On the other hand, there has been a constant search for security both in preindustrial and post-industrial social structures. However, it is a fact that the level of security needs increases in business life, especially with the technologies developing with the industrial revolution, bringing many health and safety threats (Kılkış, 2011). In this context, laws, regulations, and standards have been developed to protect against the factors threatening job security. Despite this, it was observed that the existing laws, regulations, and standards were not sufficient to ensure the health and safety of employees, and it was understood that the human factor was at least as important as other factors in working life (Tharaldsen et al., 2010). For this reason, considering the relationship of cultural differences with 
Ümit Deniz Illhan \& Derya Alimanoğlu Yemiş̧̧i / Ulusal Kültür, Örgüt Kültürü ve İş Güvenliği Kültürü̈ Ilişskisi: Hofstede'nin Gü̧̈ Mesafesi ve Belirsizlikten Kaçınma Boyutları Açısından Türkiye Özelinde Bir Değerlendirme

attitudes and behaviors related to work, national culture has been included in the research on occupational safety culture (Arezes and Miguel, 2003). As a matter of fact, national culture has been associated with a large number of organizational behavior, and occupational safety culture is one of them (Keiser, 2017).

In this study, with the idea that both organizational culture and occupational safety culture reflect national culture, the effects of national culture on occupational safety culture were examined in terms of power distance and uncertainty avoidance dimensions, which are high in Turkey according to Hofstede (1980)'s Theory of Cultural Dimensions. The study concludes that high power distance and high uncertainty avoidance in Turkey have negative effects on occupational safety culture. In this regard, recommendations developed by examining these two dimensions in terms of occupational safety culture are thought to contribute to guiding both researchers and practitioners. 